\title{
Celebrating 175 years of perovskite research: a tribute to Roger H. Mitchell
}

\author{
Anton R. Chakhmouradian · Patrick M. Woodward
}

Published online: 4 May 2014

(C) Springer-Verlag Berlin Heidelberg 2014

\section{Preface}

Few minerals have experienced as radical a makeover of their image in less than two hundred years as perovskite. From an obscure accessory phase found in equally obscure silica-undersaturated rocks $(<100$ research papers in the first 90 years of its recorded existence), perovskite and its related phases have risen to an unprecedented level of scientific popularity (3,476 publications in 2013 alone, according to SciFinder ${ }^{\circledR}$ ). The mineral was discovered by the Prussian mineralogist Gustav Rose (1839) in a piece of chlorite-rich skarn from the Akhmatovskaya Kop' (Akhmatov's Pit) in the Urals (Fig. 1), sent to him by his Russian colleague and a notable mineral collector August Alexander Kämmerer, who had undoubtedly recognized the potential scientific value of the sample, and at whose request the new mineral was named in honor of the decorated Napoleonic Wars veteran Count Lev A. Perovskiy (1792-1856). Despite his somewhat tainted reputation as a rapacious collector (Shakinko 1980), the Assistant Minister and then Minister of the Interior Perovskiy was a progressive figure in the Russian Court, noted for his key role in agrarian reforms, and the advancement of archeology, mining and lapidary enterprises (Maykov 1916). In the seven decades following the publication of Rose's original

\footnotetext{
A. R. Chakhmouradian ( $\square)$

Department of Geological Sciences, University of Manitoba,

Winnipeg, MB R3T 2N2, Canada

e-mail: anton.chakhmouradian@umanitoba.ca

P. M. Woodward

Department of Chemistry, 3109 Newman \& Wolfrom Laboratory,

Ohio State University, 100 West 18th Ave,

Columbus, OH 43210, USA

e-mail: woodward@ chemistry.ohio-state.edu
}

description (in Latin!), perovskite research focused on the apparent discrepancy between the isometric morphology of crystals from the Urals and Alps and their clearly biaxial optical character and lamellar twinning (for a brief overview, see Bowman 1908). Rooted deep in the intricacies of crystal structure, this discrepancy would ultimately be resolved only with the advent of X-ray diffraction techniques some half a century later (Kay and Bailey 1957). Although synthetic $\mathrm{CaTiO}_{3}$ and a related $\mathrm{Na}-\mathrm{Nb}$ oxide were first prepared around the same time as Verneuil's ruby, Spezia's quartz and a great many other "test-tube minerals" (Holmquist 1898), the real impetus to perovskite research came only in the 1920s with the first industrial patent (Patent US1436164)—issued to none other than Victor Moritz Goldschmidt-and with the detailed structural studies of $\mathrm{CaTiO}_{3}$ and "verwandten Verbindungen" inspired by the same Goldschmidt and conducted in Oslo by his students Thomas F.W. Barth (1925) and Frederik W.H. Zachariasen (1928). Their findings, including the now fundamental tolerance factor, were summarized in the seminal Geochemische Verteilungsgesetze der Elemente series.

In the 1940s, the pressing military and industrial need for ferroelectrics with a high dielectric constant led to the discovery of $\mathrm{BaTiO}_{3}$ ceramics (Vul and Gol'dman 1945; von Hippel et al. 1946), which propelled perovskite materials, whose prior commercial application had been virtually limited to pigments, into the electronic age (Table 1). The structure of $\mathrm{BaTiO}_{3}$ was first solved by Helen D. Megaw (1945), whose subsequent research laid the foundation for our contemporary understanding of the structural variations and phase transitions in synthetic perovskites and their relation to the diverse and often unique properties exhibited by these materials. This early work on ferroelectric ceramics not only gave rise to what is today a multibillion dollar industry (Haertling 1999), but ultimately paved the 
Fig. 1 The perovskite beginnings: a The Akhmatovskaya Kop' (type locality) in the South Urals, as it was seen by the Russian explorer and geologist Ivan V. Mushketov (1877). This locality was discovered in 1811 by Efim F. Akhmatov, Director of the Kusinskiy Iron Works near Zlatoust, and throughout the 1800 s, used as a source of valuable mineral specimens (i.e., a Kop'). In 1981, it was declared a state-protected geological monument. b A vintage specimen of chlorite-calcite skarn from the Akhmatovskaya Kop' sporting superb pseudocubic perovskite crystals up to $3 \mathrm{~cm}$ in size with a conspicuous twinning striation. This sample, now in the Fersman Mineralogical Museum in Moscow, traces its pedigree from the famous Kochubey collection, which dates back to the historical exploration of the Urals and the time of Rose, Kämmerer and Perovskiy (photo and information courtesy of Alexander A. Evseev)
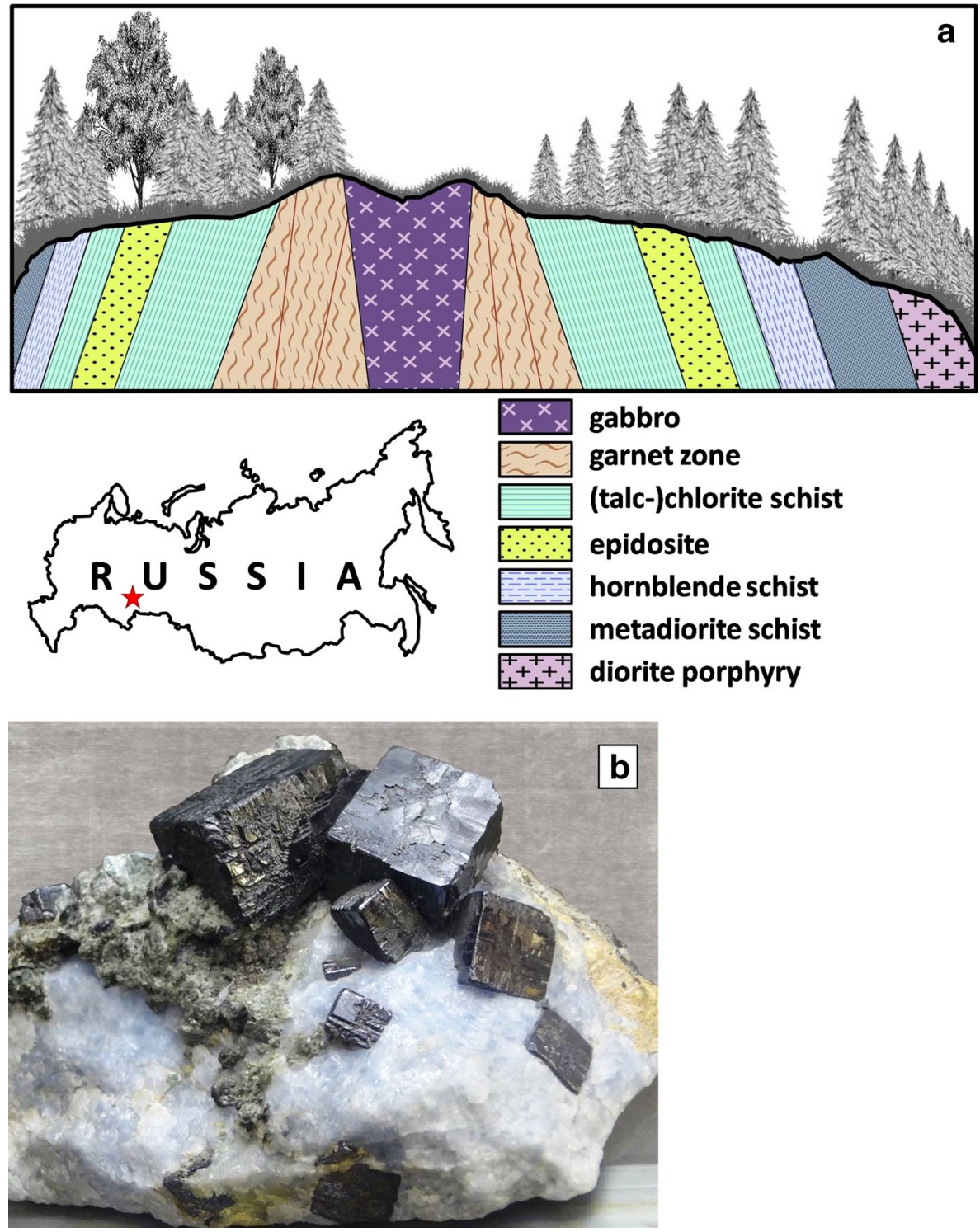

way to principally new perovskite-based technologies and materials, from barrier layer capacitors to high-temperature superconductors, high-response piezoelectrics, proton conductors, fuel cells, memory storage devices, colossal magnetoresistors (e.g., Galasso 1990; Tejuca and Fierro 1992; Kreuer 2003; Ishihara 2009; Qi et al. 2010) and, most recently, organometal halides for photovoltaic applications (Liu et al. 2013).

Known to occur, in addition to Akhmatovskaya-style skarns, in various silica-undersaturated igneous rocks ("basalts") since at least the 1870s (Bořický 1876), perovskite had, by the 1970 s, been recognized as a fairly common accessory mineral in chondrite meteorites, kimberlites and several other industrially important rocks, whereas the perovskite group already numbered six recognized species. Following the groundbreaking experimental work of Lingun Liu (1974), silicate perovskite $(\mathrm{Mg}, \mathrm{Fe}) \mathrm{SiO}_{3}$ has been identified as the principal constituent of the Earth's lower mantle (Knittle and Jeanloz 1987) and, as such, the most abundant terrestrial mineral. More recently, this phase was documented in shock-induced veinlets in meteorites (Tomioka and Fujino 1997). Tremendous implications of these discoveries for the understanding of Earth's evolution and planetary processes are reflected in the fact that more than 200 research papers and reviews have been published on $(\mathrm{Mg}, \mathrm{Fe}) \mathrm{SiO}_{3}$ in the past 40 years, easily making it one of the best-studied perovskite-type compounds to date.

In striking contrast to the progress made in the materials science and high-pressure fields (Table 1), there had been little work done on "normal-pressure" crustal perovskites prior to the 1990s; many members of that group had not even been structurally studied. This imbalance was first recognized by Roger H. Mitchell (Fig. 2a), one of the world's leading experts on lamproites, carbonatites 
Table 1 Perovskite timeline: major discoveries and breakthroughs in research and technology

\begin{tabular}{|c|c|c|}
\hline Date & Short description & Lead researcher(s) \\
\hline 1839 & $\begin{array}{l}\text { Discovery and naming of perovskite }\left(\mathrm{CaTiO}_{3}\right) \text { in a skarn ("Schisto } \\
\text { chloritico") sample from the Ural Mts., Russia }\end{array}$ & Gustav Rose (Prussia) \\
\hline 1851 & First documented synthesis of $\mathrm{CaTiO}_{3}$ (flux growth) & Jacques-Joseph Ebelmen (France) \\
\hline 1876 & $\begin{array}{l}\text { First report of perovskite from igneous rocks (melilitic rocks at } \\
\text { Děvín and elsewhere in Bohemia) }\end{array}$ & Emanuel Bořický (Bohemia) \\
\hline 1877 & $\begin{array}{l}\text { First report of extensive element substitutions in perovskite } \\
\text { ("Dysanalyt") from Kaiserstuhl carbonatites (Baden) }\end{array}$ & Adolph Knop (Germany) \\
\hline 1898 & First perovskite-type compound synthesized $\left(\mathrm{NaNbO}_{3}\right)$ & Per Johan Holmquist (Sweden) \\
\hline 1912 & Confirmation of orthorhombic symmetry of $\mathrm{CaTiO}_{3}$ & Ove Balthasar Bøggild (Denmark) \\
\hline 1922 & First industrial patent $\left(\mathrm{CaTiO}_{3}\right.$ pigment $)$ & Victor M. Goldschmidt (Norway) \\
\hline 1925 & $\begin{array}{l}\text { First description of the perovskite crystal structure } \\
\text { (done on metamorphic samples from Zermatt, Switzerland) }\end{array}$ & Thomas F.W. Barth (Norway) \\
\hline $1940 \mathrm{~s}$ & $\begin{array}{l}\text { Discovery of ferroelectric ceramics with a high dielectric constant } \\
\left(\mathrm{BaTiO}_{3}\right)\end{array}$ & $\begin{array}{l}\text { B.M. Vul \& I.M. Gol'dman (Physical Institute, USSR); } \\
\text { A. von Hippel and co-workers (MIT, USA) }\end{array}$ \\
\hline 1945 & Tetragonal structure of ferroelectric $\mathrm{BaTiO}_{3}$ determined & $\begin{array}{l}\text { Helen D. Megaw (Philips Lamps, England); Harold Percy } \\
\text { Rooksby (GE, England) }\end{array}$ \\
\hline 1946 & Key thermodynamic properties of $\mathrm{CaTiO}_{3}$ measured & C. Howard Shomate (Bureau of Mines, USA) \\
\hline 1949 & $\begin{array}{l}\text { Discovery of first "layered perovskites" (Aurivillius phases), } \\
\text { beginning with } \mathrm{Ca}_{2} \mathrm{Nb}_{2} \mathrm{Bi}_{2} \mathrm{O}_{9}\end{array}$ & Bengt Aurivillius (Stockholm University, Sweden) \\
\hline 1950 & $\begin{array}{l}\text { Discovery of ferromagnetism and magnetoresistance in } \\
\text { mixed-valence manganites, } \mathrm{La}_{1-\mathrm{x}}(\mathrm{Ca}, \mathrm{Sr}, \mathrm{Ba})_{\mathrm{x}} \mathrm{MnO}_{3}\end{array}$ & G.H. Jonker \& J.H. Van Santen (Philips, Netherlands) \\
\hline 1952 & First study of catalysis in perovskites & Giuseppe Parravano (Princeton, USA) \\
\hline 1955 & $\begin{array}{l}\text { Magnetic structures of } \mathrm{La}_{1-\mathrm{x}} \mathrm{Ca}_{\mathrm{x}} \mathrm{MnO}_{3} \text { perovskites determined by } \\
\text { neutron diffraction and used to work out the rules that govern } \\
\text { magnetic superexchange interactions }\end{array}$ & $\begin{array}{l}\text { E.O. Wollan \& W.C. Koehler (Oak Ridge National Lab, USA); } \\
\text { J.B. Goodenough (MIT, USA) }\end{array}$ \\
\hline 1955 & $\begin{array}{l}\text { Development of } \mathrm{Pb} \text { zirconate-titanate piezoelectric materials } \\
\quad\left(\mathrm{PZT}, \mathrm{PbZr}_{\mathrm{x}} \mathrm{Ti}_{1-\mathrm{x}} \mathrm{O}_{3}\right)\end{array}$ & Bernard Jaffe (Clevite Corp., USA) and co-workers \\
\hline 1958 & Discovery of relaxor dielectric materials $\left(\mathrm{PbMg}_{1 / 3} \mathrm{Nb}_{2 / 3} \mathrm{O}_{3}\right)$ & $\begin{array}{l}\text { G.A. Smolenskiy \& A.I. Agranovskaya (Semiconductor } \\
\text { Institute, USSR) }\end{array}$ \\
\hline 1958 & $\begin{array}{l}\text { Synthesis of layered derivative (Ruddlesden-Popper) phases, } \\
\text { beginning with } \mathrm{Sr}_{3} \mathrm{Ti}_{2} \mathrm{O}_{7}\end{array}$ & $\begin{array}{l}\text { S.N. Ruddlesden \& P. Popper (British Ceramic Research } \\
\text { Association, England) }\end{array}$ \\
\hline 1970 & $\begin{array}{l}\text { Discovery of perovskite in primitive meteorites (Lancé carbona- } \\
\text { ceous chondrite) }\end{array}$ & M.J. Frost \& R.F. Symes (NHM, England) \\
\hline 1970 & Discovery of perovskite-type cobaltite catalysts & D.B. Meadowcroft (CERL, England) \\
\hline 1972 & $\begin{array}{l}\text { A notation is developed for describing octahedral tilting in } \\
\text { perovskite hettotypes }\end{array}$ & A. M. (Mike) Glazer (Cambridge, England) \\
\hline 1974 & Synthesis of high-pressure silicate perovskite $\mathrm{MgSiO}_{3}$ & Lin-gun Liu (ANU, Australia) \\
\hline 1975 & $\begin{array}{l}\text { Discovery of superconductivity in perovskites }\left(\mathrm{BaPb}_{1-\mathrm{x}} \mathrm{Bi}_{\mathrm{x}} \mathrm{O}_{3} \text {, }\right. \\
\text { first low carrier density superconductor) }\end{array}$ & Arthur W. Sleight (Dupont, USA) and co-workers \\
\hline 1978 & $\begin{array}{l}\text { Perovskite-bearing ceramics (“SYNROC”) proposed for } \\
\text { immobilization of high-level radioactive wastes }\end{array}$ & A.E. (Ted) Ringwood (ANU, Australia) and co-workers \\
\hline 1981 & $\begin{array}{l}\text { Discovery of proton conduction in anion-deficient cerate perovs- } \\
\text { kites }\left(\mathrm{SrCe}_{1-\mathrm{x}} \mathrm{REE}_{\mathrm{x}} \mathrm{O}_{3-\alpha}\right)\end{array}$ & Hiroyasu Iwahara (Tottori University, Japan) and co-workers \\
\hline 1986 & $\begin{array}{l}\text { Discovery of high-T superconductivity in perovskite-type cuprate } \\
\text { ceramics }\end{array}$ & J.G. Bednorz \& K.A. Müller (IBM, Switzerland) \\
\hline 1994 & $\begin{array}{l}\text { Development of hybrid organic-inorganic halide perovskites for } \\
\text { thin-film transistor applications }\end{array}$ & David B. Mitzi (IBM, USA) and co-workers \\
\hline 2006 & $\begin{array}{l}\text { Development of a perovskite-sensitized solar cell (based on the } \\
\text { hybrid halide perovskite } \mathrm{CH}_{3} \mathrm{NH}_{3} \mathrm{PbBr}_{3} \text { ) }\end{array}$ & $\begin{array}{l}\text { A. Kojima, T. Miyasaka et al. (Tokyo Polytech and Toin } \\
\text { Universities, Japan) }\end{array}$ \\
\hline
\end{tabular}

and other igneous rocks that often contain accessory perovskite (Fig. 2b). Roger's interest in this subject, dating back to his early research on kimberlites (Mitchell 1972), led to a painstakingly systematic study of the composition, isotopic variation, paragenesis, crystal structure and phase relations of perovskite and related $\mathrm{Ti}( \pm \mathrm{Nb})$ oxides 


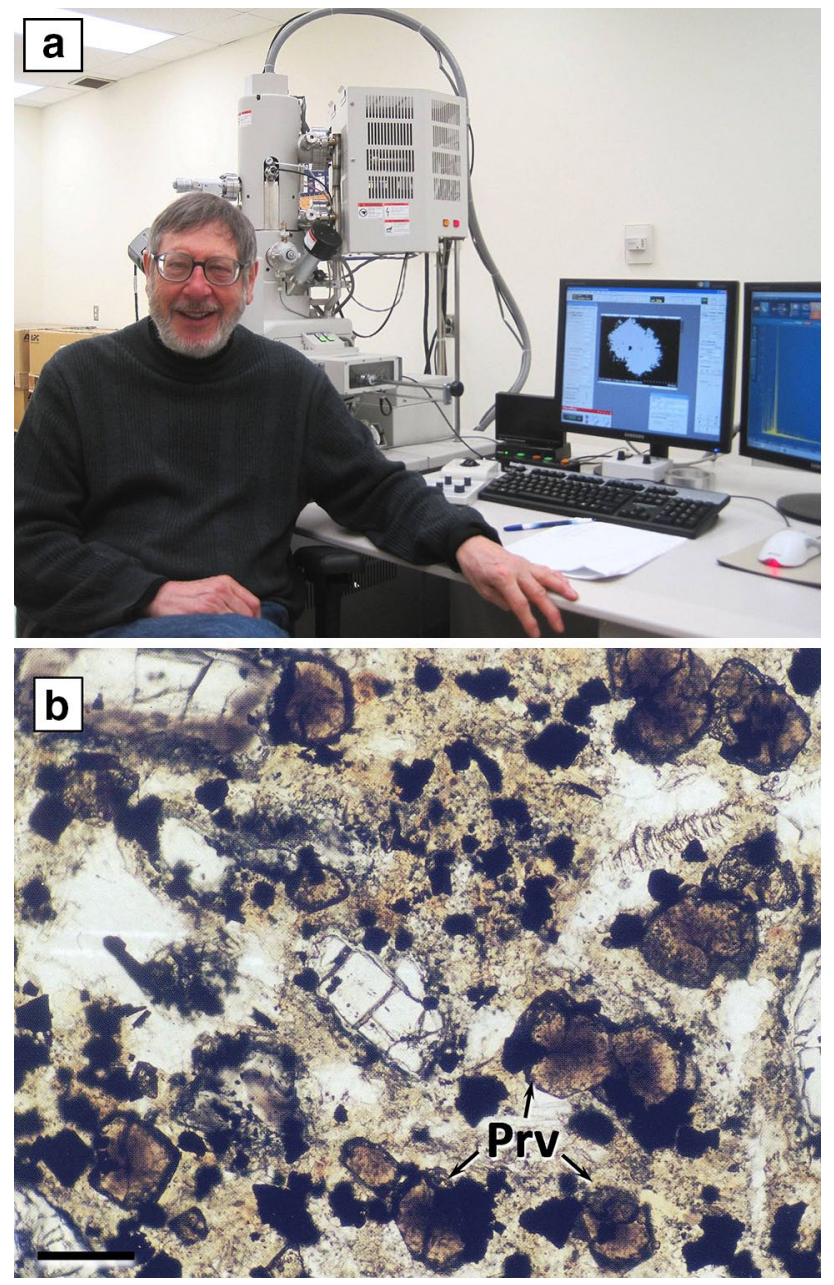

Fig. 2 a Professor Emeritus Roger H. Mitchell of Lakehead University, Canada, at his "workbench" (scanning electron microscope in the LU Instrumentation Laboratory). b A plane-polarized light image from Roger Mitchell's "Petrographic Atlas" (1997), showing multiple zoned perovskite crystals (Prv) in a matrix of the Ondermatje kimberlite, South Africa. Scale bar is $0.1 \mathrm{~mm}$

from dozens of localities around the world, as well as of composition-driven structural changes across several synthetic solid solution series of petrologic significance. Some of the problems Roger set off to tackle proved so complex that their resolution required years of dedicated effort and the use of multiple cutting-edge instruments (see, e.g., Mitchell et al., this issue). Among his greatest contributions was the demonstration of the compositional and structural complexity of naturally occurring perovskites and of their potential value as petrogenetic indicators. This work culminated in some 50 peer-reviewed papers and a monograph (Mitchell 2002) that the inventor of perovskite structural hierarchy Mike Glazer praised as "the book that I wish I had written!" (Glazer 2002). The present thematic issue is a tribute to Roger's career-long fascination with perovskites and his insightful research in that area. It is hard to think of a journal that would be more appropriate for this publication than Physics and Chemistry of Minerals, whose cover has featured the tilted perovskite octahedra since 1997 (Kohlstedt and Langer 1997).

The present issue was not meant to be a compendium, but rather a sampling of contemporary research focused on structural variations in crustal perovskites (Mitchell et al.; Demartin et al.), ( $\mathrm{Mg}, \mathrm{Fe}) \mathrm{SiO}_{3}$ perovskite and analogous phases of significance to the lower mantle (Sinmyo et al.; Gréaux et al.; Li et al.), phase transitions in perovskite and related structures induced by temperature (Zhou et al.) and pressure (Noked et al.; Zhu et al.; Knight et al.) and subsolidus alteration of $\mathrm{CaTiO}_{3}$ in silica-undersaturated rocks (Martins et al.; Zajzon et al.). We would like to take this opportunity to thank Editor Catherine McCammon for her instrumental role in bringing this issue together, and all the referees who have contributed their time and expertise to this project. Alexander Evseev is gratefully acknowledged for the perovskite photo reproduced in Fig. 1.

\section{References}

Barth T (1925) Die Kristallstruktur von Perowskit und verwandten Verbindungen. Norsk Geol Tidsskr 8:201-216

Bořický E (1876) Uiber Perowskit als mikrosckopischen Gemengtheil eines für Böhmen neuen Olivingesteines, des Nephelinpikrites. Sitzungsber Königl Böhmisch Gessels Wissens Prag 1876(6):227-236

Bowman HL (1908) On the structure of perovskite from the Burgumer Alp, Pfitschthal, Tyrol. Mineral Mag 15:156-176

Galasso FS (1990) Perovskites and High Tc Superconductors. Gordon and Breach Science Publishers, New York

Glazer AM (2002) Review of Perovskites: modern and ancient by Roger H. Mitchell. Acta Crystallogr B 58:1075

Haertling GE (1999) Ferroelectric ceramics: history and technology. J Am Ceram Soc 82:797-818

Holmquist PJ (1898) Synthetische Studien über die Perowskit- und Pyrochlormineralen. Bull Geol Inst Univ Uppsala 3(5):88

Ishihara T (ed) (2009) Perovskite oxide for solid oxide fuel cells. Springer, Dordrecht

Kay HF, Bailey PC (1957) Structure and properties of $\mathrm{CaTiO}_{3}$. Acta Cryst 10:219-226

Knittle E, Jeanloz R (1987) Synthesis and equation of state of $(\mathrm{Mg}, \mathrm{Fe}) \mathrm{SiO}_{3}$ perovskite to over 100 gigapascals. Science 235:668-670

Kohlstedt DL, Langer K (1997) Editorial. Phys Chem Miner 24:1

Kreuer KD (2003) Proton-conducting oxides. Ann Rev Mater Res 33:333-359

Liu L (1974) Silicate perovskite from phase transformations of pyrope-garnet at high pressure and temperature. Geophys Res Lett 1:277-280

Liu M, Johnston MB, Snaith HJ (2013) Efficient planar heterojunction perovskite solar cells by vapour deposition. Nature 501:395-398

Maykov P (1916) Perovskiy Lev Alekseevich. In: Military encyclopedia (in Russian). Sytin, Petrograd

Megaw HD (1945) Crystal structure of barium titanate. Nature 155:484-485

Mitchell RH (1972) Composition of perovskite in kimberlite. Am Mineral 57:1748-1753 
Mitchell RH (1997) Kimberlites, orangeites, lamproites, melilitites, and minettes: a petrographic atlas. Almaz Press, Thunder Bay

Mitchell RH (2002) Perovskites: modern and ancient. Almaz Press, Thunder Bay

Mushketov IV (1877) Materials to the study of geognosy and ore resources of the Zlatoust mining district in the South Urals (in Russian). Imper Acad Sci Press, St. Petersburg

Patent US1,436,164 (1922) Titanium pigment and process of producing same. Issued to VM Goldschmidt by the US Patent Office

Qi T, Grinberg I, Bennett JW, Shin Y-H, Rappe AM, Yeh K-L, Nelson KA (2010) Studies of perovskite materials for high-performance storage media, piezoelectric, and solar energy conversion devices. Inst Electr Electron Eng 2010:249-258

Rose G (1839) De perowskite, fossili novo. In: De novis quibusdam fossilibus quae in Montibus Uraliis inveniuntur. AG Schade, Berlin, pp 3-5
Shakinko I (1980) The mystery of one Uralian emerald (in Russian). Middle-Urals Publishing House, Sverdlovsk

Tejuca LG, Fierro JLG (eds) (1992) Properties and applications of perovskite-type oxides. Marcel Dekker Inc, New York

Tomioka N, Fujino K (1997) Natural (Mg,Fe) $\mathrm{SiO}_{3}$-ilmenite and perovskite in the Tenham meteorite. Science 277:1884-1886

von Hippel A, Breckenridge RG, Chesley FG, Tisza L (1946) High dielectric constant ceramics. Ind Engin Chem 38:1097-1109

Vul BM, Gol'dman IM (1945) Dielectric constants of titanates of metals of the second group (in Russian). Dokl AN SSSR 46:154-157

Zachariasen WH (1928) Untersuchungen über die Kristallstruktur von Sesquioxyden und verbindungen $\mathrm{ABO}_{3}$. Norsk Vidensk Akad Oslo, Mat Naturv Klasse 4:1-165 